\title{
Businesses Sustainable Strategies in Practice: The Case of Emerging Market-Kuwait
}

\author{
Sumayya A. Banna, Mohammad E. Al Mutairi, and Helen M. Hasan
}

\begin{abstract}
The burgeoning environmental sustainability stance is an escalating challenge faced by planners, leaders and decisions makers around the globe. The importance of this study provides invaluable information and insights for stakeholders in Kuwait as an example of developing countries. The key objective of this research is to explore the current environmental business sustainability and managerial practices and behavior in Kuwait. This study investigates the extent that managers in Kuwait are continuously involving in developing a vision into practices in terms of sustainability and competitive edge dimensions. This study applies $Q$ methodology to offer a complementary and alternative approach for evaluating the views on corporate environmental issues. The $Q$ study began with the concourse stage where participants were instructed to freely express their thoughts towards environmental issues when making strategic decisions. Following a refinement and clarification of the collected statements, a total of 40 statements were used for the $Q$ sort that was conducted early in 2011. There were 35 participants who successfully sorted 40 statements. The results revealed a three-factor solution and were labeled as 'Sustainable', 'Conservative' and 'Practical' managers.
\end{abstract}

Index Terms-Business sustainability, Kuwait, Qmethodology, strategic decision.

\section{INTRODUCTION}

Applying business sustainability at strategy level of any types of business might mean focusing on leadership perspective. Business owners, decision makers and managers as leaders have a strong influence as role model and can provide leadership by demonstrating their commitment to sustainability. This is reinforced by decisions that clearly show that sustainability factors have been considered.

Managers at any levels of any organizations are continuously involving in developing a vision into practices. Therefore, it is important to "walk the talk" and embed management vision into practices and encourage the managers to demonstrate the attitudes and behavior that support the vision. To be strategic in terms of sustainability dimension, managers may use a risk-benefit approach in evaluating their decisions. Identifying the sustainability risks to your business in terms of social, economic and environmental factors can help to focusing on areas that

Manuscript received October 9, 2013; revised December 11, 2013.

Sumayya A. Banna is with the Australian College of Kuwait, Kuwait (e-mail: s.banna@ack.edu.kw).

Mohammad Al-Mutairi is with the Kuwait Public Institution for Social Security Institution (KPSSI), Kuwait city, Kuwait (e-mail: mam882@uowmail.edu.au).

Helen M. Hasan is with the University of Wollongong, Australia (e-mail: hasan@uow.edu.au). could result in serious risks and costs. It is also essential to identify the potential benefits from a range of social, economic and environmental sustainability activities to see how they support your business objectives. The focus of this study on environmental sustainability practices among decision makers.

The burgeoning environmental sustainability stance is an escalating challenge faced by planners, leaders and decisions makers around the globe. Environmental issues in terms of climate change are becoming a primary corporate strategy that involves senior management as well as the board of directors of any company around the globe. Effective mitigation of environmental issues may improve the efficient use of resources and have economic impact on firms. In addition, there are significant social and economic benefits to be gained. While some companies are among the biggest emitters of carbon or greenhouse gases, companies across all sectors are required to reduce their carbon emission levels. Companies may have to respond to governmental strategies such as carbon pricing by trading or taxation that are initiated to stimulate corporations to reduce their emissions. These measures will initially increase the costs for doing business (Labatt and White 2007). The more corporations are required to drive down their carbon emissions, the more important a firm's carbon exposure becomes a management problem. Therefore, corporate managers should align sustainable activities with their primary corporate objectives, strategies and decisions to create shareholder value.

The importance of this study provides invaluable information and insights for stakeholders in Kuwait as an example of developing countries. The key objective of this research is to explore the current environmental business sustainability and managerial practices and behavior in Kuwait. It also aims to investigate magnitude that managers in Kuwait would consider environmental matters when making strategic decisions. The practicality of the existent study may permit firms to maintain sustainability and a competitive edge. From a practical perspective, it provides useful guidelines to all managers around the world, not only relevant to Kuwaiti context, about environmental business sustainability. To explore this nascent and underdeveloped issue, there is an escalating need to implement a subjective qualitative and innovative method, such as Q methodology, to give a deeper understanding of managerial business sustainable practices.

Despite the fact that Kuwait is a small Arab country located in the Middle East on the northeast Arabian Peninsula of the Asian continent, it occupies an area of 17,818 sq. km at the northern shore of the Arabian Gulf between Iraq and Saudi Arabia, and, is about one third the size of Scotland 
(CIA: The World Fact Book 2011). The population of the country is expanding rapidly, having increased by 450 percent every 25 years (Caulton and Keddie 1998). Because of a high rate of population growth in Kuwait, a noticeable increase in the rate of water use or consumption has been caused by the vast development of building construction, industrial, and agricultural activities. This imposes pressure on fresh water sources, creating water scarcity, which has led Kuwait to depend entirely on unconventional sources, such as saltwater desalination plants to meet its demand for water. To tackle these environmental challenges, the Kuwaiti government signed the Kyoto protocol on March 2005 to reduce greenhouse gas emissions. The government established the Environmental Public Authority (EPA) in 1995 and the Kuwait Institute for Scientific Research (KISR) in 1967. KISR was established to carry out scientific research related to industry, energy, agriculture, and national economy, whereas the EPA plays an active role in achieving sustainable developments by stressing the role of society in changing negative behaviors in dealing in terms of the environment and reducing greenhouse gas emissions.

Table I reports some environmental indicators for the period 2002-2007. The percentage of forest area is nearly 31 of the total land area. Emission of carbon dioxide, stemming from oil fuel combustion and manufacturing of cement is 31 tons per capita. According to the Arab forum for environment and development (2009), Kuwait is one of the Arab countries that will likely be extremely affected by climate change impacts related to sea level rise. It is estimated that 1 to 3 percent of land will be affected by a 1 meter rise in sea level.

TABLE I: ENVIRONMENTAL INDICATORS (AVERAGE 2002-2007)

Forest area (sq. km) 54.83

Forest area (\% of land area) $30.77 \%$

$\mathrm{CO} 2$ emissions (kt)

80092.6

$\mathrm{CO} 2$ emissions (metric tons per capita)

31.98355

$\mathrm{CO} 2$ intensity ( $\mathrm{kg} \mathrm{CO} 2$ per $\mathrm{kg}$ of oil equivalent energy use)

In earlier literature, the concept of sustainability was defined in terms of environmental, economic and social sustainability. Kaidonis, Stoianoff and Andrew (2010) documented the shift of meaning of the sustainability concept from global and environmental equity to reflect different meanings in different contexts. For example, sustainability is defined from business perspective in terms of accounting costs of organizational sustainability (market-adjusted returns) and, financial terms. Increasing the sustainability created an awareness in developed countries, such as the USA that generate an essential debate on the determinants of a firm's environmental critical position, action and commitment. The obvious answer for various stakeholders is who may influence management to follow a certain path (Nazim, Ray and Douglas 2003). Labatt and Maclaren (1998) suggested that the pressures from stakeholder are significant environmental motivators.

In terms of corporate social responsibility, including environmental responsibility, stakeholders generally demand integrity, transparency, accountability and standards (Waddock, Bodwell and Graves 2002). Several studies pointed to the importance of these stakeholders' demands for the development of proactive environmental strategies (Steurer et al 2005; Maxwell el al 1997). According to Schaltegger, Burrit and Petersen (2003), stakeholder groups are inspired by different motivations and encourage companies to undertake different environmental courses of action. Many studies revealed that companies' environmental strategies and practices are depending upon their perception of the relative importance of different stakeholders. For example, environmental proactive strategies are associated with greater pressure from organizational and community groups, whereas environmental reactivity is associated with greater pressure from regulatory stakeholders and the media (Henriques and Sadorsky 1999). Buysse and Verbeke (2003) indicated that environmental proactive strategies are developed through the pressure of internal primary stakeholders rather than by the pressure from external stakeholders, whereas Johnson (1998) noted that environmental decision-making are dependent on external stakeholders such as customers and suppliers.

In addition to the importance of stakeholders' awareness, managerial awareness and their active participation in achieving sustainability reflects whose overall beliefs, perceptions and attitudes. Therefore, environmental awareness of managers is a key dimension for explaining corporate environmental behavior. Several studies indicated the importance of top management support and commitment in the development of proactive environmental strategies (Nazim, Ray and Douglas 2003; Quazi et al 2001).

Evidently, there is a growing significance and emerging interest in environmental issues, particularly for societal, organizational and governmental stakeholders (Hanson et al. 2006). Environmental concerns have escalated in the wake of the increase in adverse human practices towards the environment in recent years. Although the primary focuses of environmental issues research has been on developed countries such as US and European firms, the studies on environmental business practices are still limited

\section{Methodology}

\section{A. Research Design}

In order to address the research question, a $Q$ methodological study was chosen as a mean to explore the diverse views of managers on current environmental business sustainability issues when making strategic decisions in Australia. Q methodology has been applied in various fields of social science in an attempt to uncover patterns of perspectives that are situated within people's subjectivity. For instance, it has been employed to identify views regarding public interest, environmental policy and planning of renewable energy sources (Wolsink 2004). The strengths of Q methodology lies in its suitability for topics where the respondents are not familiar with or do not have a readily constructed picture. Q methodology also does not rely on the subjects to articulate a consistent rationale; rather, the shared perspectives between respondents emerge through the factor 
analysis (Brown and Duguid 2001). Furthermore, one of its strength is that it does not require shared perspectives to be known or hypothesized in advance. From this perspective, since the environmental issues remains underdeveloped and nascent, it is important to implement a $\mathrm{Q}$ methodology to explore the hidden subjective views of business sustainable practices among managers.

Q methodology also differs from conventional quantitative methods as it is an intensive approach that typically employs a small number of respondents using many questions, rather than the reactions of a large number of people to a smaller number of questions. The factor analysis in Q methodology also differs from conventional methods, as the factor analysis represents the variance that is common to the people associated with the factor (Brown 1980; Webler, Danielson and Tuler 2009). A Q sample of 30 to 50 individuals can produce an accurate picture of the views on a topic or an issue (McKeown and Thomas 1990).

The application of Q methodology in this study is not to substitute qualitative conventional research methods but to offer a complementary and alternative approach to examine and evaluate managerial views on corporate environmental issues. To achieve this aim, this research examines the attitudes of various corporate managers in Australia, as central to the analysis. As this researcher identified, Q methodology can provide a deeper understanding of managerial thinking, which is the main focus of this research. This analysis of the subjective views of managers leads to a deeper understanding of corporate environmental practices as well as their role in the decision-making processes of management and policy makers in developed countries.

For this research study, the concourse group was encouraged to produce as many statements as they could so that they freely expressed the range of thoughts on their desired elements on the environmental issues based on their experience of the current business sustainable practices. Since Q methodology allows for free expression and they are encouraged to produce as many statements as they can. The collected statements were then redefined and clarified to remove duplicates, or combined some into one meaningful statement or simply eliminated some because of the relevancy to the topic of interest. The collection of refined ideas derived from concourse is known as Q sample and usually fewer in number than the original concourse and more defined. Apart from statements collected during the concourse, other statements are also taken from secondary sources such as journal articles for this research study. It is interesting to note that the participants in this research study were not only involved in the generation of the statements, but also exhibited interest and full involvement in the statements sorting process.

In Q-methodology studies, participants are asked to sort a collection of statements, known as the Q-sample, based on their personal experiences. For this study, participants were asked to rank order the 40 items on a scale. The resulting rankings were analyzed as factor to determine the dominate mode of thinking. Unlike the concourse, the Q-sort is conducted on individual basis.

Under the instruction of the researcher, participants were asked to make an initial reading through of the Q-sample to get the impression of the range of opinions on an issue. At the same time, the participants were asked to sort the statements into roughly three equal main categories: those statements selected to be positive statements, neutral, and negative based on their perception of the statement on the practice of using online palliative care as public health information source. The next step in sorting was to ask participants to focus on the first sets of statements then they reread that category, select the one they considered most important, and places its corresponding number under the +5 column on the $\mathrm{Q}$ sort scale as in the figures below (see Fig. 1 and Fig. 2). Then the participants continue until all of the comments in the first categories have been placed on the data sheet (Q-grid).

A similar process occurs for the remaining category with activities that are judged less important (rarely performed) being placed in the $-5,-4,-3$, and -2 category and the remaining activities filling in the middle columns of the inverted pyramid on the datasheet. The consequence of the sorting process is a forced decision making process, where the participants must decide amongst the statements and produce a result that reflects their decisions.

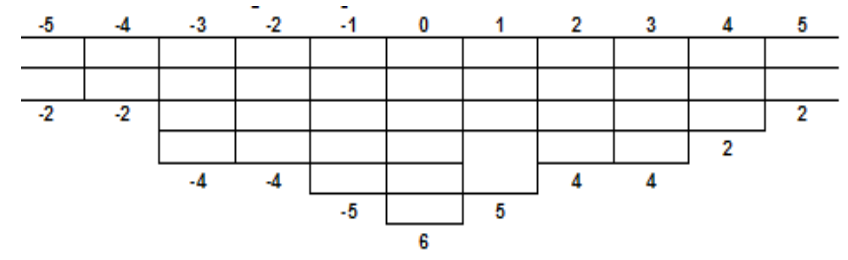

Fig. 1. Q-Sort scale.

Thus the participants sorted the statements on a Q-sort scale ranging from most agree $(+5)$ to most disagree $(-5)$. The sort distribution is showing in the following Fig. 2.

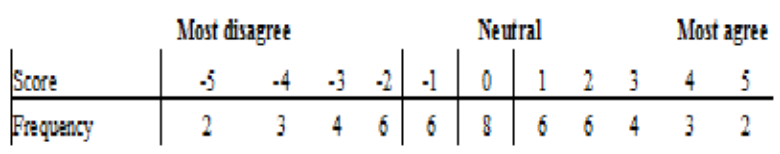

Fig. 2. Q-sort distribution.

\section{B. The Sample}

The sample size include thirty-five participants successfully sorted 40 statements that were collected to reflect the range of views that the concourse participants held on their perceptions towards environmental business issues. Each participant averaged 1 hour to complete the study.

\section{The Questionnaire}

The questionnaire consists of two main parts: a demographic section, which asked for information about the participants and their feedback on the collected statements, and the Q-sort scale figure, along with the 40 items.

\section{Analysis}

The participants' responses were statistically analyzed to find correlations and identify Factors that are common to the sorts of several individuals (Stephenson 1953). The analysis is the longest part of the task and the difficulty will depend on the relative clarity of the factors that are produced. "PCQ" software is used to assist with the mechanics of the analysis. 
A software known as PCQ software was used to perform the mechanics of the analysis. The data from all the sorts was entered into the software package, which was run to generate the factors. Each factor would typically be comprised of several sorts (people). After using the varimax rotation for a simple factor structure, the researcher then examined who loaded significantly on a particular factor to determine what similarities their rankings shared. The selection of the factors is primarily a result of the correlation, as it is the correlation or similarity of the sorts that determines the factors. The number of factors identified depends in part upon the extent or degree of agreement amongst subjects and in part, on how much detail the researcher feels is useful to analyze. The factors are not necessarily mutually exclusive in that a given statement or a given individual may appear on more than one factor.

\section{RESULTS}

The Q methodology approach was used to investigate the subjectivity and the insights of managerial behavior of environmental practices. This phase was undertaken to gather data on how environmental decisions are perceived in the light of this dynamic business environment. This phase involved a small sample from Kuwait. The researcher decided to collect information from participants in Kuwait from graduates (part-time and full-time) students and (part-time and full-time) academic staff in the university as well as some members of the general public which will be discussed later in Section C. It was assumed that these groups were relatively representative of the decisions makers worldwide, as this is a global phenomenon.

The Q study began with the concourse stage where participants were instructed to freely express their thoughts towards environmental issues when making financial decisions. In addition, some statements are collected from secondary sources such as journal articles. Following a refinement and clarification of the collected statements, a total of 40 statements were used for the Q sort that was conducted earlier in year 2011. The participants in this research study were not only involved in the generation of the statements, but also exhibited interest and full involvement in the second stage, the statements sorting process. In total, there were 20 participants or sorts from Kuwait who successfully sorted the 40 statements as illustrate in Appendix I.

\section{A. Three Factor Solution Data for the Kuwaiti Sample}

For the Kuwaiti Q sample, a three-factor solution was selected as the best guided criteria and ultimate selection. These three groups still share some similarities and differences based on consensus and factor correlations results. The criteria demonstrated in Table II which also includes variance, number of confounded sorts, number of non-significant sorts and number of sorts. The three-factor solution explained 27 percent of the variance compared to other factors with 20 participants or fifty seven percent of participants loaded into the 3 -factor.

Results also identified that there are five consensus items, as shown in Table III and their factor scores for this solution.
Consensus items are those received same or very similar. They are items for which all participants held similar opinions. Obviously, these consensus statements neither help to define the characteristics of the sample population nor are useful for defining the differences between factors. They do however provide insight in this case to the commonly held or overarching views, such as, the priority given to compliance.

TABLE II: A COMPARISON FOR 3 TO 7 FACTOR SOLUTIONS FOR KUWAITI Q SAMPLE

\begin{tabular}{c|cccr}
\hline $\begin{array}{c}\text { No. of Factors } \\
3\end{array}$ & Variance (\%) & No. of Confounded & No. of non-significant & No. of Sorts \\
4 & 27 & 0 & 15 & 20 \\
\hline 5 & 33 & 2 & 16 & 17 \\
\hline 6 & -39 & 3 & 13 & 19 \\
\hline 7 & -43 & 2 & 9 & $\frac{19}{24}$ \\
\hline
\end{tabular}

\begin{tabular}{|c|c|c|c|c|}
\hline No. & Statements & $\overline{F 1}$ & $\overline{F 2}$ & $F 3$ \\
\hline 1 & $\begin{array}{l}\text { The economic crisis was the driver for } \\
\text { organization to implement corporate and } \\
\text { environmental sustainability program. } \\
\text { The implications of climate change in business }\end{array}$ & 2 & 2 & 1 \\
\hline 8 & $\begin{array}{l}\text { sustainability are uncertain. } \\
\text { There is a posi tive correlation between corporate }\end{array}$ & 1 & 0 & 0 \\
\hline 11 & $\begin{array}{l}\text { financial performance and the environment. } \\
\text { Economic opportunities are one of the drivers of }\end{array}$ & -1 & 0 & -1 \\
\hline 18 & $\begin{array}{l}\text { corporate environmental strategy. } \\
\text { Environmental costs are one main component of } \\
\text { total cost that must be taken into account for better }\end{array}$ & 0 & -1 & -1 \\
\hline 40 & decision making. & 0 & 1 & 1 \\
\hline
\end{tabular}

TABLE IV: ELEVEN ITEMS THAT DiSTINGUISH FACTOR 3 FROM ALL OTHER FACTORS

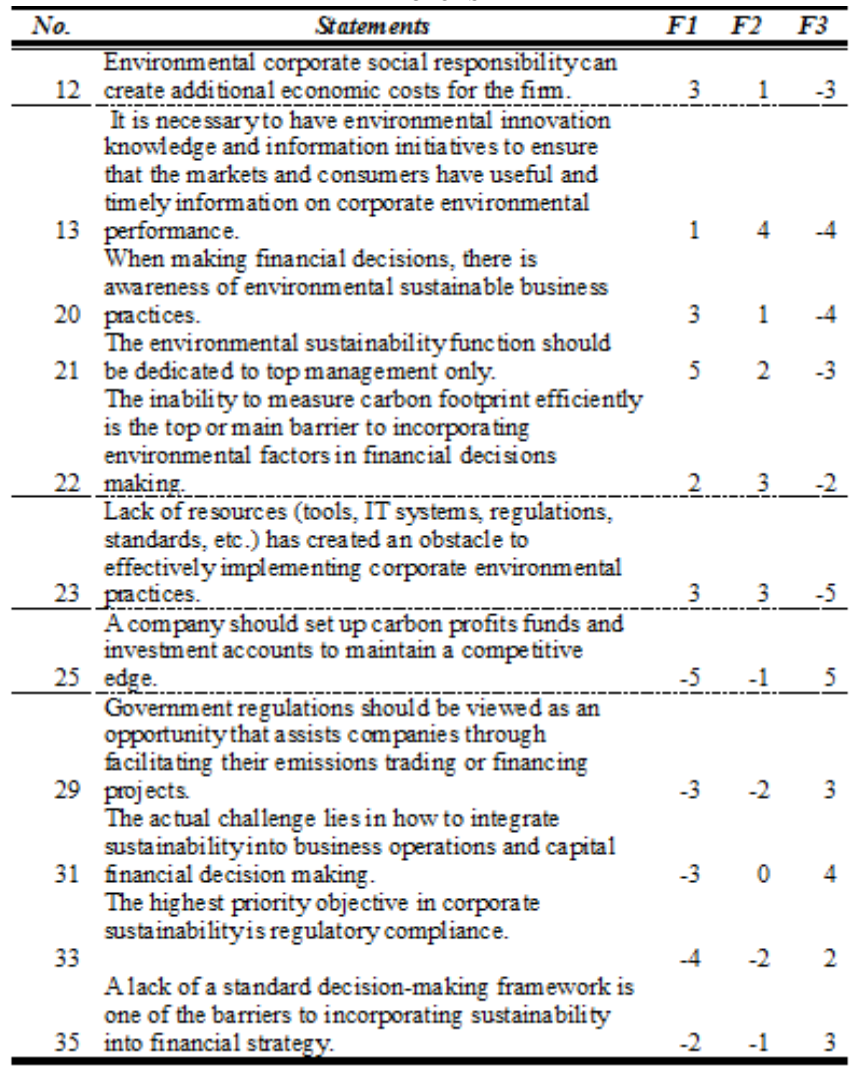

On the contrary, the distinguished items in Table IV-Table VI are the statements that can be extremely useful. These statements are helpful when it comes to distinguishing between factors and considering the differences in normalized Z-scores, item by item, for the entire Q sample. Statements with large normalized Z-scores (both high positive and negative) can clarify the differences between the factors. 
TABLE V: TEN ITEMS THAT DISTINGUISH FACTOR 3 FROM ALL OTHER FACTORS

\begin{tabular}{|c|c|c|c|c|}
\hline No. & Statements & F1 & $F 2$ & $F 3$ \\
\hline & $\begin{array}{l}\text { Corpora te decision makers must evaluate } \\
\text { potential environmental risks that can aff }\end{array}$ & & & \\
\hline 3 & $\begin{array}{l}\text { corporate objectives and the planning process. } \\
\text { There is an alignment between environmental }\end{array}$ & 0 & -4 & \\
\hline 6 & $\begin{array}{l}\text { business practices and overall corporate strategy. } \\
\text { Companies today are capable to mea sure } \\
\text { environmental outcomes, e.g. annual energy use or }\end{array}$ & -1 & 4 & -1 \\
\hline 7 & greenh & 4 & -3 & \\
\hline 9 & $\begin{array}{l}\text { among managers in today's company. } \\
\text { Companies must report their environmental } \\
\text { performance to the community in either a financial } \\
\text { annual report or via other published sources, or, on }\end{array}$ & 0 & 5 & -2 \\
\hline 10 & the Internet. & 1 & -5 & - \\
\hline & $\begin{array}{l}\text { pted environmental stra teg ycan influence } \\
\text { e strate gic investments and consequently }\end{array}$ & & & \\
\hline 16 & finat & 2 & -5 & \\
\hline & $\begin{array}{l}\text { Lack of environmental interest from stakeholders, } \\
\text { i.e. investors, top management, etc. has impeded } \\
\text { the implementation of environmentally sustainable }\end{array}$ & & & \\
\hline 24 & $\begin{array}{l}\text { business practices and strategy. } \\
\text { A company should set up carbon profits funds and } \\
\text { investment accounts to maintain a competitive }\end{array}$ & -2 & 5 & \\
\hline 25 & edge. & -5 & -1 & \\
\hline & $\begin{array}{l}\text { One of the main objectives } \\
\text { focus on developing a new }\end{array}$ & & & \\
\hline 27 & scheme. & -4 & 3 & -2 \\
\hline 30 & $\begin{array}{l}\text { Behavioural } \\
\text { reduce carbo }\end{array}$ & 3 & -2 & \\
\hline
\end{tabular}

TABLE VI: THREe ItEMS ThAT Distinguish FACTOR 3 FROM ALl OTHER FACTORS

\begin{tabular}{llccc}
\hline No. & \multicolumn{1}{c}{ Statements } & F1 & F2 & F3 \\
\hline 19 & Green revolution would affect every business activity. & 4 & -3 & 0 \\
& $\begin{array}{l}\text { Company should set up carbon profits funds and } \\
25\end{array}$ & & & \\
investment accounts to maintain a competitive edge. & -5 & -1 & 5 \\
& One of the main objectives of the firm should be to focus \\
28 & on reducing carbon taxes. & -3 & 3 & 5 \\
\hline
\end{tabular}

\section{B. Factor Correlation}

The correlations express the relationship between factors. It is helpful to express a very specific part of a relationship and connection between sorts as reflected by their presence in the factors. Thus, the high correlation between factors indicates similarity between the sorts correlation designates the extent of difference between the sorts. The correlation between the three-factors varied ranging from -28 between factor 1 and factor $3 ;-20$ between factor 2 and factor $3 ; 2$ between factor 1 and factor 2 and so on. The big difference between the three-factors, on the other hand, meant that they have little in common. For this reason, the variations in the correlations became clearer as each factor evaluated and reviewed then a comparison conducted between each one of them. Details on correlations are shown in Table VII.

TABLE VII: CORRELATION BETWEEN FACTORS 1 TO FACTOR 4

\begin{tabular}{|c|c|c|c|}
\hline & Factor 1 & Factor 2 & Factor 3 \\
\hline $\begin{array}{l}\text { Factor } 1 \\
\text { Factor } 2 \\
\text { Factor } 3\end{array}$ & $\begin{array}{c}0 \\
2 \\
-28\end{array}$ & $\begin{array}{c}2 \\
0 \\
-20\end{array}$ & $\begin{array}{c}-28 \\
-20 \\
0\end{array}$ \\
\hline
\end{tabular}

\section{Discussion}

To identify the managers' behavior on environmental business practices, a three-factor solution has been selected.
The managers' perceptions on the environmental business sustainable practices were analyzed and interpreted based on the factor types, which emerged. The study named these three factors as 'Sustainable, 'Conservative', and 'Practical' managers. As revealed in Section 9.8, the results showed 6 participants (17 percent) in Factor 1, the 'Sustainable' group, 9 (26 percent) in Factor 2, the 'Conservative' group, and only 5 (14 percent) in Factor 3, the 'Practical' group.

\section{1) Factor 1: sustainable managers}

Factor 1 consists of a total of 6 managers, as illustrated in Table VIII. There were all males and no females in factor 1 . It is interesting to note that the Kuwaiti sample is the managers from listed firms on the KSE. Among the 6 males, there was 1 investment manager with a Bachelor degree, who happened to have over 10 years of experience at his career in a listed company in Kuwait, was between the age 26 of 35 ; 3 finance managers with Bachelor degrees, 2 with 4-10 tenure and 1 over 10 years (ages 36-45). The last group includes 3 finance managers with 4-10 years tenure at their current job who were between the ages of 46 and5.

TABLE VIII: THE DEMOGRAPHIC INFORMATION FOR FACTOR

\begin{tabular}{lllll}
\hline Age & No. Participants & Education & Position & Tenure \\
\hline $26-35$ & 1 & Bachelor & Investment manager & over 10 years \\
$36-45$ & 3 & Bachelor & Finance manager & $2(4-10), 1$ over 10 ye ars \\
$46-55$ & 2 & Bachelor & Finance manager & $4-10$ years \\
\hline \hline Total & 6 & & \\
\hline
\end{tabular}

Appendix II contains the statements with the high agree (positive) and the high disagree (negative) for each of the three-factor, factor 1 , factor 2 and factor 3.

Factor 1, the 'Sustainable' group is entirely composed of middle managers including finance and investment managers. Environmental awareness is particularly important for Factor 1 as specified in statements 2 and 20. For this reason, 'Sustainable' middle managers, value the importance of environmental business practices. They prioritizes top management's decision-making, which can have a substantial impact on every business activity, and thus, affect future success of business, as indicated by statements 21,19 and 4.

One strategies of employing environmental consciousness is being proactive rather than reactive. Environmentally proactive managers are shown in their behavioral changes towards the environment at every level of the firm as indicated in statement 30 . There is also indications that being environmentally consciousness and proactive may lead to long term-economic gain (Bandley 1992; Shi and Kane 1995). 'Sustainable' managers also value the environmentally sustainable business as being an essential component of their corporate social responsibility (CSR) when making decisions. In general, Corporate Social Responsibility (CSR) encompasses the economic, legal, ethical and philanthropic expectations placed on firms by society (Carroll and Buchholtz 2002). Some researchers argue that being socially responsible can place organizations at economic disadvantage because any additional activities can add costs to the firms (Guerard, Bean and Andrews 1987; Hay, Gray and Gates 1976). Therefore, the establishment of environmentally friendly business practices can expose firms 
to economic distress, as viewed by 'Sustainable' managers in statement 12 . This group of managers also recognizes their capabilities and limitations as indicated in statements 7 and 23. 'Sustainable' managers are responding to the challenges of climate change in a way that strengthens their core business strategy by measuring environmental impact through reducing their greenhouse gases emissions and saving energy. As a result, greater returns are realized as CSR becomes more integrated into core business strategy through achieving efficiency through cost-benefits analysis and creation of a win-win scenario (Cruz 2008). One of the key hindrances for 'Sustainable' manager is lack of resources, which entails information technology tools, governmental regulations and standards that impeded the implementations of environmental business practices. This finding is in-line with previous researchers, including Verbruggen et al. (2009). Accordingly, this group opposes the view that the highest objective in corporate sustainability is regulatory compliance because this does not assist companies through facilitating their emissions trading or financing projects, as specified in statements 33 and 29.

Since there is no market for carbon trading that exists in Kuwait, a corporation's primary objective should not be to focus on formulating a new carbon trading scheme and/or reduction of carbon taxes as reflected in statements 27 and 28 . Consequently, the argument that firms need to set-up a carbon investment account to maintain a competitive edge and sustainability in the market place is opposed, as indicated in statement 25 . Therefore, active engagement is not required to deal with risk management in the investment accounts, as indicated by finance and investment managers' views in statement 38. Furthermore, there is incapability among managers to measure the effect of carbon on shareholder's value or the financial performance of the firm.

\section{2) Factor 2: conservative managers}

Factor 2 consists of 9 participants and all managers for listed firms in KSE, as shown in Table VIIII. This factor is comprised of only males and no females. The males were comprised of one strategic performance manager who holds a MBA degree with 4-10 tenure (age 26-35); and, three managers: 2 with an MBA and 1 with a Bachelor degree and all 4-10 tenures (age 36-45). The last group in factor 2 consists of 5 finance managers: 1 holds an MBA with 27 years old tenure and 4 have a Bachelor degree with 4-10 tenure (age 46-55).

TABLE VIIII: THE DEMOGRAPHIC INFORMATION FOR FACTOR 2

\begin{tabular}{|c|c|c|c|c|}
\hline Age & No. Participants & Education & Position & Tenure \\
\hline $26-35$ & 1 & MBA & Strategic performance & $4-10$ years \\
\hline $36-45$ & 3 & 1 Bachelor and $2 \mathrm{MBA}$ & $\begin{array}{r}2 \text { finance and } 1 \text { investment } \\
\text { managers }\end{array}$ & $4-10$ years \\
\hline 46.55 & 5 & $1 \mathrm{MBA}$ and 4 Bachelor & 5 finance managers & $\begin{array}{r}4(4-10) \text { years } \\
\text { and } 1(27 \\
\text { years })\end{array}$ \\
\hline Total & 9 & & & \\
\hline
\end{tabular}

Factor 2, the 'Conservative' group is characterized as having their attention largely focused on the specific external and internal barriers that hamper environmental business sustainability practices and strategies such as lack of stakeholder's interest, innovative knowledge and information, IT tools and resources and carbon foot-prints measurement, as specified in statements 24, 13, 23 and 22. Appendix III lists their most agreed and disagreement statements. This finding is in-line with previous studies, including Ren 2009; Walker, Di Sisto and McBain 2008; Sharma and Vredenburg 1998. To some extent, this factor is composed of 3 top managers. According to this group, the climate change risk has been addressed among managers in today's world and there are integrations between sustainable practices and overall corporate strategy, as indicated in statements 9 and 6. From this perspective, decisions makers must not evaluate potential risk that may affect corporate objectives and planning, as shown in statement 3. This Factor's tradition also possesses opposition to the argument that environmental strategy can have essential strategy on corporate strategic investment and its financial performance, as indicated in statement 16.

The 'Conservative' managers tend to considerably focus on corporate primary environmental objectives, such as reduction of carbon taxes, an, developing new carbon trading scheme, as shown in statements 28 and 27. Although there is no market for trading carbon in Kuwait, this group of traditional managers is considered to be proactive through their anticipation of the future market demand and incorporate carbon taxes strategy as well as developing a carbon trading scheme.

This group of traditional managers tends to resist the concept of carbon reporting or disclosure to the public, as shown in statement 10 . These managers also disagree on any kind of pressure from any interest stakeholders' groups in Kuwait as enablers to formulate corporate environmental strategy, as in statement 15 . Moreover, this group does not believe that business ethics can play an important role behind implementations of corporate environmental strategy.

It is interesting to note that there is similarity between this Factor and Factor 1 as there is an agreement that there is lack of knowledge on measuring carbon emissions on shareholders' value and therefore the financial performance of the firms, as indicated in statement 34 . In contrast to 'Conservative' managers, this group of traditional managers does not believe that climate change may have any effect on business activity because they are incapable of gauging the efficiency of consumed resources, as reflected in statements 19 and 7.

\section{3) Factor 3: practical managers}

Factor 3 consists of 5 male participants from listed firms on the KSE in Kuwait, as shown in Table X. This factor is comprised of 4 males who hold Bachelor degrees with 4-10 years tenure at this point in their current career; among these 4 males, 3 were finance managers and 1 was an investment manager, and, their ages were $36-45$ years old; one manager, with a Bachelor degree, had 4-10 years of experience in his current job position (age 46-55).

TABLE X: THE DEMOGRAPHIC INFORMATION FOR FACTOR 3

\begin{tabular}{lrlll}
\hline Age & No. Participants & Education & Position & Tenure \\
\hline $36-45$ & 4 & Bachelor & 3 finance and 1 investment managers & $4-10$ tenure \\
$46-55$ & 1 & Bachelor & Manager & $4-10$ tenure \\
\hline Total & 5 & & \\
\hline
\end{tabular}

Factor 3, the 'Practical' group have realistic considerations in setting up a carbon and investment account 
and reducing carbon taxes to enable the firm to maintain a competitive edge, as revealed in statements 25 and 28 . Appendix IV lists their most agreed and disagreement statements. This group also requires behavioral change that involves all corporate elements, including employees and staffs, to ensure reduction of carbon emissions, as indicated in statement 30 . This factor sees that the actual challenge lie in 'how to integrate sustainability into business operations and capital financial decisions making' (statement 31). However, this group views that integrating corporate social responsibility in environmental strategy does not create any additional economic costs to the firm, as designated by statement 23. This finding contradicts the finding from Factor 1 where 'Sustainable' managers' view environmental strategy and activities that direct firms to additional economic distress. It is interesting to note that these realistic managers were not aware of an environmental issue when making financial decisions, as reflected in statement 20 .

\section{CONCLUSION}

This research adopted a $\mathrm{Q}$ methodology approach to explore managers' perceptions, and it explicitly supports and offers a significant contribution to this field of research in which the subjectivity of participants' views is critically important. Q

Future work could also involve interviews with participants in different factor groups to explain more about why they placed the statements accordance with either the most agreed $(+5)$ or most disagree $(-5)$, so that a broader perspective can be obtained on reasons that would make certain choices in their use of environmental business issues.

Certainly, more research is also desperately needed on environmental issues as it is still in its nascent stage. Future research should investigate, through case studies or empirical research, the changes in firms' performances after adopting environmental strategies in Kuwait or any developing or any other developed country. In other words, future study may examine the impact of adopting environmental business practices on overall business performance in terms of firms' value and profitability.

\section{APPENDIX}

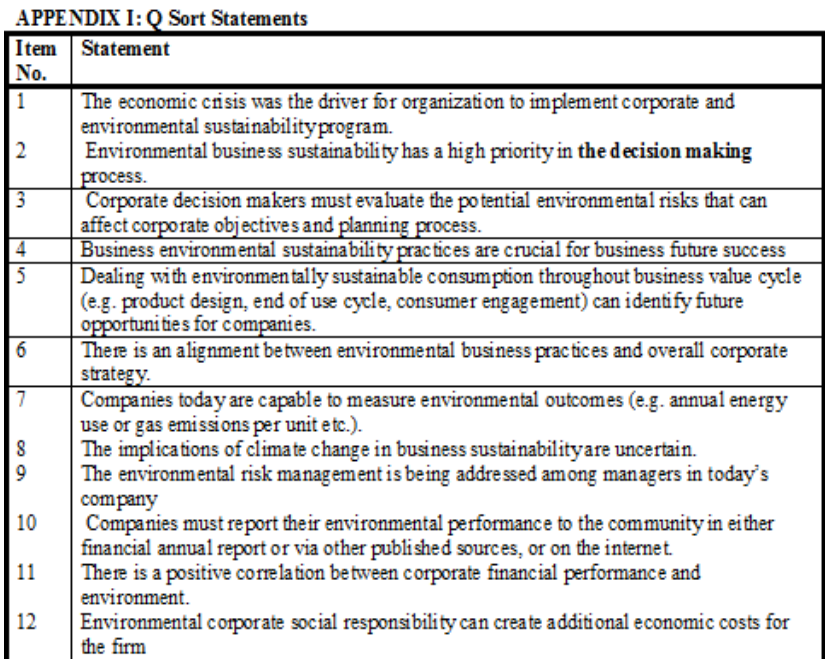

\begin{tabular}{|c|c|}
\hline 13 & $\begin{array}{l}\text { is necessary to have environmental innovation knowledge and information initiatives } \\
\text { ensure that the markets and consumers have use ful and timely information on } \\
\text { rporate environmental performance. }\end{array}$ \\
\hline 14 & $\begin{array}{l}\text { The early environmental mover company, through environmentally friendly process and } \\
\text { product innovation can build a competitive edge }\end{array}$ \\
\hline 15 & $\begin{array}{l}\text { The pre ssure of different drivers (i.e. government, employees, suppliers environmental } \\
\text { organizations) of environmental responsiveness can shape the company's environmental } \\
\text { strategy } \\
\text { The adopted environmental strategy can influence corporate strategic investments and } \\
\text { consequently financial performance. }\end{array}$ \\
\hline 17 & $\begin{array}{l}\text { e company's ethical motivations is one of the driver behind implementing corporate } \\
\text { vironmental strategy }\end{array}$ \\
\hline 18 & onomic opportunities is one of the drivers of corporate environmental strategy \\
\hline 19 & een revolution would affect every business activity. \\
\hline 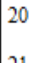 & $\begin{array}{l}\text { When making financial decisions, there is awareness of environmental sustainable } \\
\text { business practices. }\end{array}$ \\
\hline 21 & tainability function should be dedica \\
\hline 22 & $\begin{array}{l}\text { pmain barrier of incorporating } \\
\text { ds etc.) has created an obstacle } \\
\text { es. }\end{array}$ \\
\hline 24 & $\begin{array}{l}\text { top management...etc.) has } \\
\text { practices and strategy. }\end{array}$ \\
\hline 25 & ccount to maintain a \\
\hline 26 & $\begin{array}{l}\text { hhould support the carbon R\&D research departments. } \\
\text { n objective of the fim should focus on developing new emission/carbon }\end{array}$ \\
\hline 120 & of the main objective of the firm should focus on reducir \\
\hline 0 & $\begin{array}{l}\text { that assists companies } \\
\text { cts }\end{array}$ \\
\hline 30 & Behavioural change at firm level is required to reduce carbon emission \\
\hline 31 & $\begin{array}{l}\text { The actual challenge lies in how to integrate sustainability into business operations and } \\
\text { capital financial decision making }\end{array}$ \\
\hline 32 & $\begin{array}{l}\text { The actual challenge lies in how to implement susta inability into business operations and } \\
\text { capi tal financial decision making in a large complex profitable firms }\end{array}$ \\
\hline 33 & $\begin{array}{l}\text { The highest priority objective in corporate sustaina bility are regulatory compliance } \\
\text { The greatest barriers to incorporate sustainability into financial strategy include the } \\
\text { inability to measure the effects of sustainability on shareholder value }\end{array}$ \\
\hline 3. & $\begin{array}{l}\text { A lack of standard decision-making framework is one of the barrier to incorporate } \\
\text { sustainability into financial strategy }\end{array}$ \\
\hline 36 & $\begin{array}{l}\text { Organizational resistance is the least significant challenge to incorporate sustainability } \\
\text { into financial strategy }\end{array}$ \\
\hline 37 & $\begin{array}{l}\text { Inability to document the effects of shareholder value on financial performance in one of } \\
\text { the barriers to incorporate sustainability into financial strategy }\end{array}$ \\
\hline 38 & $\begin{array}{l}\text { Active management engagement in the invested companies is necessary to address } \\
\text { environmental risk in their investment portfolio }\end{array}$ \\
\hline 39 & relationship between climate change and company's financial risk \\
\hline 40 & Environmental costs ate one main component of total cost that must be taking \\
\hline
\end{tabular}

Appendix III: Array of Z-Scores ( \pm 1 ), Agree and Disagree Statements for Factor 2

Lack of environmental interest from stakeholders, i.e. investors, top

management, etc. has impeded the implementation of

24 environmentally sustain able business practices and strategy. 1.708

$9 \quad \begin{aligned} & \text { Environmenta1 risk management is being addressed a mong managers } \\ & \text { in today's company. }\end{aligned}$

It is necessary to have environmental innovation knowledge and

information initiatives to ensure that the markets and consumers

mance.

There is an alignment between environmental business practices and

There is an alignment between environmental business practices and
-overall corporate strategy.

28 reducing carbon taxes.

Lack of resources (tools, IT systems, regulations, standards, etc.) has created an obstacle of effectively implementing corporate

environmenta1 practice

One of the main objectives of the firm should be to focus on

developing a new emission/carbon trading scheme.

The inability to measure a carbon footprint efficiently is one of the

22 top, main barriers to incorporating environmental factors in financial $\quad 0.915$

\begin{tabular}{|c|c|c|}
\hline o & Statement & Z-Score \\
\hline & $\begin{array}{l}\text { Companies must report their environmental performance to the } \\
\text { community in either a financial annual report or via other published } \\
\text { sources, or, on the Internet. }\end{array}$ & \\
\hline & $\begin{array}{l}\text { The adopted environmental strategycan influence corporate strategic } \\
\text { investments and consequently financial performance }\end{array}$ & 47 \\
\hline & $\begin{array}{l}\text { Corporate decision makers must evalua te } \\
\text { risks that can affect corpora te objectives an }\end{array}$ & 4 \\
\hline 17 & $\begin{array}{l}\text { The company's ethical } \\
\text { implementing corpora }\end{array}$ & 44 \\
\hline & $\begin{array}{l}\text { The pressure of differen } \\
\text { environmental organizat }\end{array}$ & \\
\hline & & 17 \\
\hline & $\begin{array}{l}\text { s today are capa } \\
\text { lenergyuse or }\end{array}$ & .098 \\
\hline & & \\
\hline & & \\
\hline
\end{tabular}

\begin{tabular}{|c|c|c|}
\hline No. & Statement & Z-Score \\
\hline 25 & $\begin{array}{l}\text { A company should set up carbon profits funds and investment } \\
\text { accounts to maintain a competitive edge. }\end{array}$ & 0.964 \\
\hline & One of the main objectives of the firm should be to focus on & \\
\hline 28 & $\begin{array}{l}\text { reducing carbon taxes. } \\
\text { Behavioural change at the firm level is required to reduce carbon }\end{array}$ & 0.635 \\
\hline 30 & emissions. & 0.63 \\
\hline 31 & $\begin{array}{l}\text { The actual challenge lies in how to integrate sustainability into } \\
\text { business operations and capital financial decision making. }\end{array}$ & 0.503 \\
\hline
\end{tabular}

\begin{tabular}{|c|c|c|}
\hline No & Statement & Z-Score \\
\hline 23 & $\begin{array}{l}\text { Environmental corporate social responsibility can create additional } \\
\text { economic costs for the firm. }\end{array}$ & -1.063 \\
\hline 17 & $\begin{array}{l}\text { The company's ethical motivations are one of the drivers behind } \\
\text { implementing corporate environmental strateg } y\end{array}$ & -0.489 \\
\hline 20 & $\begin{array}{l}\text { When making financial decisions, there is a wareness of } \\
\text { environmental sustainable business practices. }\end{array}$ & -0.484 \\
\hline
\end{tabular}




\section{REFERENCE}

[1] P. Bandley, "Green is a buy signal," Far Eastern Economic Review, vol. 155 , pp. 36, 1992.

[2] J. S. Brown and P. Duguid, "Knowledge and organization: a social practice perspective," Organization Science, vol. 12, pp. 198, 2001.

[3] S. R. Brown, "Political subjectivity: applications of Q methodology in political science," in New Haven, Yale University Press, 1980.

[4] K. Buysse and A. Verbeke, "Proactive environmental strategies: a stakeholder management perspective," Strategic Management Journal, vol. 24, pp. 453, 2003.

[5] A. B. Carroll and A. K. Buchholtz, Business and Society: Ethics and Stakeholder Management, South-Western Publishing, Cincinnati, Ohio, 2002.

[6] E. Caulton and D. Keddie, "Environmental conversation problems in Kuwait," The Environmentalist, vol. 9, pp. 219, 1989.

[7] CIA-World Fact. (2010). [Online]. Available: https://www.cia.gov/library/publications/download/download-2010

[8] J. Cruz, "Dynamics of supply chain networks with corporate social responsibility through integrated environmental decision-making," European Journal of Operational Research, vol. 184, pp. 1005, 2008.

[9] J. B. Guerard and A. S. Bean, "R\&D management and corporate financial policy," Management Science, vol. 33, pp. 1419, 1987.

[10] R. D. Hay, E. R. Gray et al., Business and Society, South Western, Cincinnati, Ohio, 1976.

[11] I. Henriques and P. Sadorsky, "The relationship between environmental commitment and managerial perceptions of stakeholder importance," Academy of Management Journal, vol. 42, pp. 87,1999.

[12] M. A. Kaidonis and N. Stoianoff, A Handbook of Corporate Governance and Social Responsibility, I. G. A. a. D. C. Ed. Gower Publication, Farnham, England, 2010.

[13] S. Labatt and V. MaClaren, "Voluntary corporate environmental initiatives: a typology and preliminary investigation," Environmental and Planning, vol. 16, pp. 191,1998.

[14] S. Labatt and R. White, Carbon Finance: The Financial Implications of Climate Change, John Wiley and Sons Inc., Hoboken, New Jersey, 2007.

[15] J. Maxwell, S. Rothenberg et al., "Green schemes: corporate environmental strategies and their implementation," California Management Review, vol. 39, pp. $118,1997$.

[16] B. F. McKeown and D. B. Thomas, Q Methodology, Sage Publication, Newbury Park, California, 1990.

[17] A. Nazim, V. Ray et al., "Environmental concerns, efforts and impact: an empirical study," American Journal of Business, vol. 18, 2003.

[18] H. A. Quazi, Y. Khoo et al., "Motivation for ISO14000 certification: development of a predictive model," Omega, vol. 29, pp. 525, 2001.

[19] T. Ren, "Barriers and drivers for process innovation in the petrochemical industry: a case study," Journal of Engineering and Technology Management, vol. 26, pp. 285, 2009.

[20] S. Schaltegger, R. Burritt, and H. Peterson, An Introduction to Corporate Environmental Management: Striving for Sustainability, Sheffield, Greenleaf, 2003.

[21] S. Sharma and H. Vredenburg, "Proactive corporate environmental strategy and the development of competitively valuable organizational capabilities," Strategic Management Journal, vol. 19, pp. 729, 1998.

[22] S. J. Shi and J. M. Kane, "Growing a green marketing strategy," Business and Society Review, vol. 93, pp. 51, 1995.

[23] R. Steurer, M. E. Langer et al., "Corporations, stakeholders and sustainable development I: A theoretical exploration of business-society relations," Journal of Business Ethics, vol. 61, pp. 263-281, 2005

[24] A. Verbruggen, M. Fischedick et al., "Renewable energy costs, potentials, barriers: conceptual issues," Energy policy, vol. 38, no. 2 pp 850-861, 2009.
[25] S. A. Waddock, C. Bodwell, and S. B. Graves, "Responsibility: The new business imperative," Academy of Management Executive, vol. 16, no. 2, pp. 132-148, 2003

[26] H. Walker, L. D. Sisto, and D. Bain, "Drivers and barriers to environmental supply chain management practices: lessons from the public and private sectors," Journal of Purchasing and Supply Management, vol. 14, no. 1, pp. 69-85, 2008.

[27] T. Webler, S. Danielson, and S. Tuler. (2009). Using Q Method to Reveal Social Perspectives in Environmental Research, Greenfield MA: Social and Environmental Research Institute. [Online]. Available: https:// www.seri-us.org/pubs/qprimer.pdf

[28] M. Wolsin, "Policy beliefs in spatial decisions: contrasting core beliefs concerning space-making for waste infrastructure," Urban Studies, vol. 41, pp. 2669, 2004.

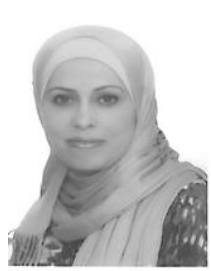

Sumayya A. Banna presently joined the Australian College Kuwait (ACK); originally from Amman-Jordan. She earned her Ph.D. degree from the University of Wollongong, NSW Australia in year 2011. While working on her Ph.D., she successfully conducted tutorials in marketing and Business units. She was awarded Uuniversity Postgraduate Scholarship (2010) commerce student awards from University of Wollongong, Australia. Her thesis is about online health and palliative care in Australia, this area of study requires a great deal of knowledge and expertise. She was a former member of activity-based usability, laboratory at the university (ATUL) in UOW, Australia. She graduated from University of Texas at Dallas (UTD), USA with master and bachelor degrees in Business Administration and awarded Cum Laude for high GPA. She has published in Information System including usability testing and content analysis, Strategic Management, and Activity Theory using Q Methodology. She has successfully managed King Abdullah grant for Hakeem Medical High diploma, in 2013. While working at Princess Sumaya University (PSUT) as an assistant professor in Jordan.

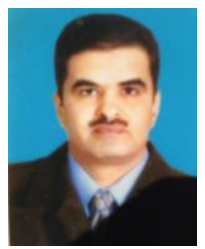

Mohammad E. Al-Mutairi is an advisor of General department at Kuwait Public Institution for Social Security Institution (KPISS). He has been working as internal auditor for over 22 years in KPISS. He earned his Ph.D. degree with high commendation for its excellence from University of Wollongong in year 2011 in Accounting and Finance. He has published in in top journals for corporate finance, carbon finance, emerging markets, ownership, and corporate governance. He successfully manages his own business in car parts and mechanic repair. His master of science in finance degree is from University of Jordan and bachelor of science in Accounting is from Kuwait University.

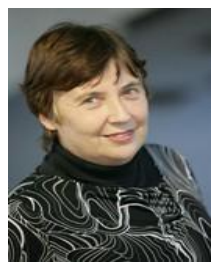

Helen Hasan was born in Sydney, on November 11, 1945. She is an associate professor of Information Systems (IS) in the Faculty of Business at the University of Wollongong, Australia. She has published extensively in IS and related areas of Human Computer Interaction, Serious Games, Group Decision Support Systems, Knowledge Management, Green IS and Sensible Organization using frameworks of Complex Activity. Helen manages an activity-based usability, laboratory at the university and co-directs both the THEORI Research Centre and the Social Innovation Network. She has led several government-funded, cross institutional research projects and conducts industry-based consulting. She leads local, national and international special interest groups on Green IS. In2012, Helen received the Vice-Chancellor's award for research student supervisor of the year 